\title{
DE ATATÜRK A ERDOĞAN: A REPÚBLICA DA TURQUIA EM TRÊS TEMPOS
}

\author{
FROM ATATÜRK TO ERDOĞAN: \\ THE REPUBLIC OF TURKEY IN THREE TIMES
}

\author{
Monique Sochaczewski ${ }^{12 *}$
}

\begin{abstract}
Resumo: Este artigo propõe revisão histórica da República da Turquia, estabelecida em 1923. Trata inicialmente dos anos formadores de Atatürk, apresenta a complexidade do período que vai de 1938 a 2002 e os vários golpes militares que então ocorreram, focando, por fim, no período de domínio do partido AKP, tendo Recep Tayyip Erdoğan como primeiro-ministro e depois como presidente.
\end{abstract}

Palavras-chave: República da Turquia; Mustafá Kemal Atatürk; Recep Tayyip Erdoğan; Islã; Islã político.

\begin{abstract}
The article proposes a historical review of the Republic of Turkey, established in 1923. It deals initially with the formative years of Atatürk, and then presents the complexity of the period from 1938 to 2002 and the various military coups that then occurred. At the end, the focus is on the period of domination of the AKP party, with Recep Tayyip Erdoğan as prime minister and, afterwards, as president.
\end{abstract}

Key-words: Republic of Turkey; Mustafá Kemal Atatürk; Recep Tayyip Erdoğan; Islam; political Islam.

\section{Introdução}

Uma ponte. Essa é quase que a imediata imagem que os turcos evocam para falar de seu país atual. Não raro citam as pontes que ligam as porções europeia e asiática de Istambul como símbolos de fato do que se consideram: uma ponte entre o Ocidente e o Oriente, historicamente entre o Cristianismo e o Islã e entre produtores e consumidores de petróleo. Nos últimos tempos, tornou-se também uma ponte (ou um muro) para muitos refugiados sírios em rota para a Europa. A Turquia definitivamente é um país com relações históricas, étnicas, culturais e religiosas com diferentes partes do tabuleiro global. E os turcos de hoje, mesmo sob o impacto da corrente crise política, também se entendem de maneira plural. Para alguns, são cosmopolitas e globalizados. Para outros, são únicos e desconfiados, afeitos ao lema "o melhor amigo de um turco é outro turco". Há ainda os que se entendem como sendo justamente o meio do caminho: uma síntese entre Europa e Ásia, um elo entre as civilizações ${ }^{3}$. Talvez a imagem de um caleidoscópio, proposta pela

${ }^{1}$ Monique Sochaczewski é doutora em História, Política e Bens Culturais pelo Centro de Pesquisa e Documentação de História Contemporânea do Brasil da Fundação Getulio Vargas (CPDOC-FGV) e autora do livro Do Rio de Janeiro a Istambul: contrastes e conexões entre o Brasil e o Império Otomano (1850-1919), publicado em 2017. ORCID ID: https://orcid.org/0000-0003-3758-6255. Link para o Currículo Lattes: http://lattes.cnpq.br/0330940402405646. Contato: moniquesgoldfeld@gmail.com

$2^{*} \mathrm{~A}$ autora agradece os comentários e sugestões feitos ao texto por Ariel González Levaggi, pesquisador da Koç University (Istambul) e ao apoio na pesquisa por parte da ex-aluna da Pós-Graduação em Relações Internacionais da PUC-Rio, Lucimar Dias.

${ }^{3}$ Não por acaso a Turquia é copatrocinadora da iniciativa da Aliança das Civilizações, no âmbito da Organização das Nações Unidas, desde seu início, em 2004. Ver: <https://bit.ly/2t7PtHz>. Acesso em 4 mar. 
diplomata sueca Ann Dismorr em seu livro Turkey decoded (2004), seja a que faça mais sentido para pensarmos os turcos e seus muitos matizes.

A República da Turquia de fato se relaciona com e até mesmo integra pelo menos três diferentes regiões. Sua conexão com o Oriente Médio, por exemplo, se deve aos fatos de ter sido núcleo duro do Império Otomano (1299-1922), que governou boa parte da região desde o século XVI; de 99\% de sua população professar o Islã; e de contar com longas fronteiras com Irã, Iraque e Síria. Por abranger territórios na Europa - inclusive a parte mais pulsante de Istambul, sua mais famosa cidade -; ter um ministério da União Europeia que lida com sua demanda para tornar-se membro desta; e conexões profundas com os Bálcãs, não há como não levar em conta sua relevância para o Velho Continente. Além disso, há uma dimensão "túrquica" e euroasiática em função de conexões étnicas e interesses energéticos com azerbaijaneses, cazaquistaneses e uzbequistaneses, entre outros, e pode ainda ser entendida no contexto político do Cáucaso do Sul e da Ásia Central.

No âmbito deste texto, o interesse é ressaltar a complexidade de relações da Turquia, tendo em vista seu passado recente como uma república, estabelecida em 1923. A abordagem, para tanto, é histórica, lançando mão de uma grande revisão da literatura referendada sobre a República da Turquia, com eventual pesquisa empírica a fim de ilustrá-la com exemplos.

0 artigo divide-se assim em três partes, cada qual interessada em ressaltar aspectos políticos - internos e externos -, sociais e econômicos do país. A primeira delas trata da fase inicial da república, quando esta foi governada por Mustafá Kemal Atatürk (19231938). 0 segundo tópico dedica-se à época que vai da morte de Atatürk à eleição do Partido Justiça e Desenvolvimento (Adalet ve Kalkınma Partisi, AKP), tratando, portanto, do longo período que vai de 1938 a 2002. Já o terceiro e último tópico dedica-se ao governo do AKP, iniciado em 2002, focando-se principalmente na atuação de Recep Tayyip Erdoğan, tanto como primeiro-ministro (2003-2014) quanto como presidente, chegando aos dias atuais, em que justamente se discute uma nova configuração política do país por conta da mudança de regime político em referendo recente.

0 texto compõe-se, portanto, como um grande voo de pássaro sobre um país que cada vez mais atrai a atenção de acadêmicos brasileiros e latino-americanos, seja em função das conexões entre os respectivos países, como também pelas muitas comparações possíveis ${ }^{4}$.

Nicole e Hugh Pope, jornalistas europeus anteriormente residentes em Istambul, destacam que no lugar de escolher partidos em função de suas ideias e princípios, os turcos elegem líderes, de alguma forma buscando alguém com a estatura de um segundo Atatürk (POPE; POPE, 2004, p. 65). Ao avançar por informações sobre mudança social, demanda por participação popular na política e conflito entre elites, nos deparamos,

2017.

${ }^{4}$ A esse respeito, ver, em especial, capítulos escritos por Ariel González Levaggi, Elena Lazarou e Milan Yan Nascimento, Guilherme Casarões, Nilüfer Narlı e Leonardo Nelmi Trevisany em Turquía-América Latina y el Caribe. Una asociación emergente (LEVAGGI; FEREZ, 2016). Já no que diz respeito ao interesse crescente de acadêmicos turcos pelo Brasil, vale conferir a tese de doutorado defendida em 2016 por Segâh Tekin, na Selçuk Üniversitesi (Brezilia'nın Diş Politikası: Gelenek ve Değişim). 
sobretudo, com o contraponto entre lideranças fortes, como se só estas fossem capazes de enfrentar os muitos desafios da nação. 0 primeiro desses líderes forjou um Estado secular e ocidentalizado, mesmo que composto por 99\% de muçulmanos. Já o segundo deles esboça uma nova entidade política que inicialmente se apresentava mais como "democrática conservadora" do que islamista, mas que nos últimos tempos se afasta das regras democráticas, estendendo por longos períodos leis de exceção.

\section{0 período de Atatürk (1923-1938)}

Ao longo do século XIX, a evidente fraqueza otomana diante das potências ocidentais era conhecida como a "questão do Oriente": a questão de que uma vez que a dissolução do Império Otomano parecia iminente, as potências europeias deveriam salvaguardar seus interesses militares, estratégicos e comerciais nesses domínios. A Rússia apostou no seu declínio, e a Grã-Bretanha se empenhou em sua preservação a fim de manter o equilíbrio de poder. Atribui-se ao czar russo Nicolau I (que reinou entre 1825 e 1855) o apelido de "doente da Europa" em função dessas disputas sobre os "restos" do Império Otomano. Com todas as dificuldades, porém, este resistiu ao longo do século XIX.

No começo do século XX a sobrevivência otomana já se mostrou mais difícil. As guerras em curso durante o governo dos Jovens Turcos - como a guerra da Tripolitânia e as guerras dos Bálcãs - enfraqueceram-no a tal ponto que a antiga "periferia" árabe do Império Otomano era rateada entre ingleses e franceses pelo Acordo Sykes-Picot (1916) e, com o fim da Primeira Guerra Mundial, a capital otomana, Constantinopla, se viu ocupada pelos Aliados. Restava saber o que aconteceria com o núcleo central do Império Otomano, e a figura do militar Mustafá Kemal se mostrou essencial nesse período: primeiramente como líder do Movimento Nacionalista Turco, no âmbito da chamada Guerra da Independência (1919-1923), e depois como seu primeiro presidente e lançador das bases do Estado turco (1923-1938). É sobre esse período e, especialmente, sobre essa figura que trataremos aqui.

As negociações no imediato pós-Primeira Guerra Mundial, como o Armistício de Mudros e o Tratado de Sèvres, impunham ao sultão Mehmet VI Vehdettin (r. 1918-1922) profundas e humilhantes alterações no desenho do Império Otomano. Por este tratado, datado de 1920, seu território deveria ser dividido, com a criação de uma Armênia independente no leste e de um Curdistão autônomo no sudeste. 0 resto do país seria rateado entre franceses, italianos e gregos, e os Estreitos seriam desmilitarizados e colocados sob controle internacional (POPE; POPE, 2004, p. 55). Pelo Tratado de Sèvres, os turcos só dominariam 15\% do que fora outrora o Império Otomano. Bernard Lewis (1968, p. 247) ressalta ainda que esse acordo era mais pesado do que o Tratado de Versalhes, imposto à Alemanha no mesmo contexto pós-guerra, e foi recebido com um feriado de luto na Turquia.

Enquanto o sultão Mehmet VI Vehdettin vivia a ocupação e aceitava o que lhe 
ditavam na Europa, grupos nacionalistas turcos, sentindo-se profundamente traídos por seu governante, recrudesciam sua resistência à política da então capital, propondo diversos projetos para o futuro do Império Otomano. Alguns defendiam até mesmo um mandato norte-americano (KINROSS, 1965, p. 196). Essas resistências eram inicialmente variadas e descoordenadas, mas ao longo de 1919 se organizou uma série de acordos e conferências justamente visando unificar os diversos movimentos independentes, em busca de uma única voz. 0 jovem oficial militar Mustafá Kemal, que tinha sido originalmente enviado pelo sultão para a Anatólia a fim desmobilizar tropas otomanas depois da guerra, desobedeceu a suas ordens iniciais e acabou se destacando no âmbito da resistência, justamente procurando unificá-la e dar-lhe um norte claro.

Mustafá Kemal (nascido na cidade de Salônica, na Macedônia otomana, em 1881) fizera parte do Comitê União e Progresso (CUP) desde seus anos iniciais. Quando o CUP chegou ao poder, em 1908, foi enviado por longas temporadas a regiões distantes da capital, atuando na Guerra da Tripolitânia (1911) e na Guerra dos Bálcãs (1912-1913), e destacando-se durante a Primeira Guerra Mundial na importante batalha de Galípoli, em 1915. Justamente quando se desenrolava a campanha de Galípoli, em que otomanos e alemães lutaram contra tropas francesas e as chamadas tropas ANZAC (de soldados originários da Nova Zelândia e da Austrália, do Império Britânico) em uma sangrenta batalha na qual os primeiros levaram a melhor, também acontecia não muito longe dali, na Anatólia, o chamado genocídio armênio. 0 fato de Mustafá Kemal ter se destacado como militar na batalha e não ter envolvimento com o genocídio, além do fato de possuir largo carisma e tino político, certamente serviria de elemento agregador internamente e legitimador externamente na liderança do movimento que se organizava.

Em junho de 1919 foi estabelecido o Acordo de Amasya, que conclamava um movimento nacional contra as potências ocupantes e estabelecia que a independência se daria com base nas províncias, e não em termos de "raça". Já o Congresso de Sivas, de setembro do mesmo ano, uniu pela primeira vez todos os líderes do movimento, que concordavam com a constituição de um parlamento que substituiria a estrutura de governo de então. Organizou-se, assim, a Grande Assembleia Nacional, em Ancara, em abril de 1920, tendo Mustafá Kemal como seu primeiro presidente.

Em paralelo aos debates políticos, estabeleciam-se também frentes de batalha na Anatólia: contra os gregos em Esmirna, contra os franceses e os colaboradores armênios em Adana e contra os armênios em Erzurum. A tomada e o incêndio de Esmirna, em 1922, seria talvez o momento mais dramático da denominada Guerra de Independência da Turquia.

Com a vitória turca no que chamam de sua Guerra de Independência, veio o Tratado de Lausanne, em 24 de julho de 1923, colocando-se no lugar do já citado Tratado de Sèvres. Deu-se então, de fato, o fim da ocupação por parte dos Aliados, consolidando-se a vitória da nova entidade política que se esboçava. 0 Tratado de Lausanne estabeleceu em grande medida as fronteiras atuais da Turquia - com exceção de Hatay, como se verá adiante - e 
com ele o mundo reconheceu oficialmente o país que os nacionalistas turcos construíram para si próprios sobre as ruínas otomanas (POPE; POPE, 2004, p. 58).

Estabeleceu-se então uma enorme mudança política, social e mesmo econômica, em que o Império Otomano, um califado islâmico, dava espaço para uma república nacional secular ${ }^{5}$. Esse período é conhecido como o da "Luta Nacional" e foi quando se deu o desmantelamento de instituições prévias e a criação de outras novas. Em novembro de 1922, o Império Otomano foi extinto com a abolição do sultanato. A república foi declarada em outubro de 1923, tendo Mustafá Kemal como seu presidente até 1938 e, inegavelmente, lançou as bases do país que ainda hoje existe. Seu objetivo era criar uma nação moderna, nos moldes ocidentais, que se impusesse sobre as cinzas de um Estado tido como corrupto, decadente e atrasado, como era visto o Império Otomano em sua fase final.

O califado a princípio tinha sido mantido pelo movimento nacional turco, mas acabou sendo abolido em março de 1924, impactando dessa vez todo o mundo muçulmano sunita. Mustafá Kemal temia que o califa pudesse representar algum tipo de resistência à sua autoridade, e ao mesmo tempo tal figura não condizia mais com o projeto nacionalista republicano turco, laico, que se tinha em mente. 0 califa foi deposto e toda a dinastia otomana foi exilada, tendo os descendentes homens só recebido autorização para retornar ao país na década de 1970 .

Sociedades de Defesa dos Direitos Nacionais forjaram o Partido do Povo, de Mustafá Kemal, e a Grande Assembleia Nacional deu lugar ao Parlamento Nacional. A Assembleia mudou a capital de Istambul para Ancara e aprovou uma nova constituição em 1924. Tentativas de restauração do sultanato, pela nova legislação, passavam a ser consideradas como atos de alta traição (FINDLEY, 2010, p. 248).

Estabeleceu-se então um governo modernizador, mas não exatamente democrático. Quando da Guerra da Independência Mustafá Kemal tinha sua liderança militar inconteste, o novo regime se legitimava pela vitória na luta nacional e por dizer-se representante da nação inteira sem distinção de grupos ou classes. Já quando do estabelecimento do novo Estado, o governo já não era tão unânime: acabou suprimindo seus oponentes e estabelecendo desde o início um largo culto à personalidade de seu líder. Por conta de uma tentativa de assassinato em junho de 1926, Kemal reagiu ampliando a punição para além dos culpados de fato, livrando-se de inimigos e ameaças em potencial (FINDLEY, 2010, p. 251) e criando a imagem de uma Turquia ameaçada por inimigos internos e externos.

Ainda quando da Guerra de Independência, Mustafá Kemal, visando apoio dos curdos, havia se comprometido a ter boas relações com estes, mantendo o califado (por conta da religiosidade do grupo) e a província de Mossul; mas tão logo nascia a República da Turquia, nenhuma promessa foi de fato cumprida. Os curdos revoltaram-se em fevereiro de 1925 e foram violentamente suprimidos, foi estipulada uma lei marcial e houve enforcamentos públicos dos culpados. Na realidade, entre 1924 e 1938, houve dezoito revoltas curdas (FINDLEY, 2010, p. 251). Desde então a "questão curda" - como lidar com

\footnotetext{
${ }^{5}$ Uma ampla historiografia ressalta que, na realidade, a República da Turquia e o Império Otomano são mais um continuum do que, por exemplo, o que ocorre entre Império Russo e União Soviética (KARPAT, 2004, p. 1).
} 
seu nacionalismo "concorrente" ou como os inserir na sociedade, "turquificando-os" ou permitindo que mantenham sua singularidade étnica e linguística - se coloca como uma questão central na Turquia.

Iniciava-se também uma era de profundas reformas religiosas, sociais e políticas. No âmbito religioso, além da deposição do califa, os sermões de sexta-feira passavam a ser em turco e "em harmonia com a ciência e o conhecimento". O Ministério de Assuntos Religiosos bem como o escritório do Sheik do Islã foram extintos, as ordens religiosas (tarikats) fechadas, e houve confisco dos recursos das fundações religiosas. 0 Ministério da Educação passava a supervisionar o treinamento dos imams. O Islã foi inclusive retirado da constituição como religião oficial do Estado, em uma emenda de 1928, embora, ironicamente, pela primeira vez o Estado tivesse ampla maioria muçulmana. Por conta do genocídio armênio em $1915^{6}$ e das fugas e mortes de gregos no âmbito da Guerra de Independência, bem como da troca populacional entre gregos e turcos em 1923 (cerca de 90 mil gregos saíram de terras turcas e 40 mil turcos vieram de terras gregas), a histórica presença cristã na "Turquia" foi reduzida a pouquíssimos milhares. A religião muçulmana passava a estar sob a supervisão do Estado mais do que separada deste. Em 1937, era a vez do secularismo se tornar lei, integrando a Constituição.

As transformações sociais desse período são conhecidas como "revoluções de Atatürk", uma vez que alteraram drasticamente a forma de vida de quase toda a população e se deram de maneira rápida, brutal e mesmo traumatizante. Passou-se a impor as roupas que eram comuns "às nações civilizadas do mundo" (KINROSS, 1965, p. 472), não só abolindo o fez e o turbante como também tornando criminoso aquele que insistisse em seu uso. 0 calendário cristão foi adotado, e o domingo passou a ser oficialmente o dia de descanso, no lugar da sexta-feira. As pessoas passaram a ter que adotar sobrenomes, tendo Mustafá Kemal escolhido Atatürk, "Pai dos Turcos", como o seu. 0 código civil foi alterado, igualando homens e mulheres e proibindo a poligamia. Em 1934 foi estabelecido o voto feminino, dez anos antes que a França, modelo de tantas reformas, o fizesse. A nova legislação se inspirava em modelos europeus, sobretudo da Suíça para o código civil, da Itália para o código penal, e da Itália e da Alemanha para questões comerciais.

0 alfabeto, originalmente em letras árabes, foi alterado em poucas semanas, em 1928,

\footnotetext{
${ }^{6} 0$ tema ainda hoje envolve sérias controvérsias no meio político turco e internacional (sobretudo em países como EUA, França e Argentina, que foram destino de larga diáspora armênia), sendo um dos mais importantes casos de "passado sensível". Já levou ao assassinato de jornalistas, a atentados contra historiadores (como Stanford Shaw) e a processos contra escritores premiados turcos, como Orhan Pamuk e Elif Şafak, por terem feito declarações reconhecendo os massacres de armênios em 1915 como genocídio. Heitor Loureiro (2016, p. 52-59) é o historiador brasileiro com expertise no tema e mobiliza autores como Donald Bloxham, Sean McMeekin e Eric Hobsbawm para declarar: "Para além dos 1-1,5 milhão de mortos, centenas de milhares de refugiados em campos no Oriente Médio - além de tantos outros que conseguiram permanecer no Império Otomano, escondidos por famílias muçulmanas e, muitas vezes, adotando a religião - e a expropriação econômica das propriedades e negócios que os armênios conduziam, o genocídio armênio deu uma nova dimensão à causa armênia, dotando-a de novas pautas: inicialmente a questão de ajuda aos milhares de cristãos armênios que estavam em situação de risco nos arredores de cidades como Aleppo, Damasco e Beirute, ou às jovens que haviam sido recolhidas por famílias turcas e curdas e viviam como muçulmanas na Anatólia, ou ainda aos milhares de órfãos que haviam perdido seus pais durante as deportações e haviam sido separados de seus familiares sobreviventes".
} 
para letras latinas. Buscava-se ainda "purificar" o turco retirando as influências persas e árabes. 0 passado otomano tornava-se literalmente inacessível ao povo por conta da mudança do alfabeto e da língua de uma maneira geral. Por outro lado, "inventou-se" uma história turca na Anatólia, ligando-a à história antiga e rica de povos como hititas e frígios, o que buscava gerar orgulho e autoconfiança nos cidadãos. Uma Sociedade Nacional de História foi criada em 1931, e uma Sociedade Nacional de Língua no ano seguinte. História e língua foram, portanto, bastante politizadas e ficaram sob as mãos do Estado. Criaram-se ainda as chamadas Casas do Povo em boa parte da Anatólia, encarregadas da educação da população para o novo Estado que se esboçava.

Como ressalta Carter Findley (2010, p. 262), uma característica importante dogoverno de Atatürk é que este foi muito mais voltado para questões internas, de estabelecimento de um novo tipo de Estado, do que para questões externas, não enfrentando ameaças externas de vulto até a Segunda Guerra Mundial. Atatürk procurou ressaltar a especificidade do lugar que a Turquia ocupava no mundo de então, como nação pacífica, sem interesse em tomar nenhum território de outrem nem com ambições políticas sobre outros países. Seu lema era "paz em casa, paz no mundo".

A diplomacia foi então usada com cuidado, buscando honrar os compromissos internacionais. Um Tratado de Amizade Turco-Soviético foi assinado em 1921, ainda no contexto da luta nacional, e revisado em 19257. Em 1926 houve um contencioso com os britânicos em relação ao status de Mossul, com os turcos alegando que essa cidade foi ocupada depois do Armistício de Mudrus. Mossul acabou perdida e tornou-se parte do estado do Iraque, mas a Grã-Bretanha pagou 10\% dos recursos de petróleo da região por vinte e cinco anos.

Se por um lado a Turquia perdeu Mossul, por outro foi aceita na Liga das Nações em 1932 e recebeu dos franceses a província síria de Hatay, em 1939. Buscou reconciliar-se com os inimigos da Guerra de Independência, Grécia e Grã-Bretanha, contando inclusive com uma visita do primeiro-ministro grego, Eleftherios Venizelos, em 1930. Não descuidou da fronteira oriental também, assinando um acordo com o Irã em 1934, recebendo seu xá em visita e assinando o Pacto de Saadabad com este, com o Iraque e o Afeganistão. Além disso, a Convenção de Montreaux, assinada na Suíça em 20 de julho de 1936, permitiu à Turquia militarizar os Estreitos.

O desenvolvimento da indústria teve grande atenção por parte do governo, e bancos e empresas estatais foram criadas, tais como Iş Bak, Sumerian Bank e Eti Bank. A ideia era que estas instituições ajudassem a criar uma classe média turca capaz de ocupar o lugar dos estrangeiros (KINROSS, 1965, p. 509). Houve ainda um grande esforço para eliminar o controle destes sobre a infraestrutura de transporte, com a nacionalização não só das ferrovias como também da navegação e da exploração de tabaco. A verdade, porém, é que o

\footnotetext{
${ }^{7}$ Norman Stone (2010: 158) ressalta que as relações com os soviéticos então, que envolveram larga ajuda financeira aos turcos, levou também a Turquia a receber Trotsky, em 1929, quando este foi expulso por Stalin e esse ainda não se considerava forte o suficiente para assassiná-lo. Trotsky viveu quatro anos na ilha de Büyükada, no Mar de Marmara, próximo à Istambul.
} 
país se configurava como exportador de matérias-primas e importador de manufaturados.

Como se vê, trata-se de uma década e meia de amplas e profundas transformações sociais, religiosas e políticas, levando o país de um império multiétnico, multilinguístico e multirreligioso a um estado nacional laico e ocidentalizado. Estabeleceu-se então o "kemalismo", ou "atatürkismo", que costuma ser apresentado com uma divisão em seis flechas: estatismo, reformismo, nacionalismo, secularismo, republicanismo e populismo (FINDLEY, 2010, p. 258). As reformas, porém, não se deram de forma igual por todo o país, e de certa forma ampliaram as desigualdades entre campo e cidade.

Foram lançadas nessa fase as bases da Turquia moderna, e o líder de então foi uma das figuras mais importantes não só de seu país, pois também teve grande impacto em diversos outros, sobretudo no mundo islâmico, com imitações de suas políticas e ações em países como Afeganistão, Irã e mesmo no Egito de Nasser (STONE, 2010, p. 157).

Mustafá Kemal faleceu de cirrose hepática em 10 de novembro de 1938, às 9h05 da manhã. Desde então, todos os anos nesse mesmo dia e hora, uma sirene é tocada na Turquia, e os cidadãos param onde estiverem para um minuto de silêncio em sua memória. Apesar de mudanças nos últimos tempos a seu respeito, trata-se, como ressalta Findley (2010, p. 262), do único dos líderes dos anos 1930 ainda reverenciado por seus compatriotas. E como ressalta Dismorr (2008, p. 24), o culto em torno de seu legado é único para um país democrático, sendo na realidade muito difícil para alguém que nunca viveu na Turquia de fato entendê-lo. Atatürk teve largo domínio em vida e uma longeva aura mítica post-mortem.

\section{Os muitos desafios da democracia (1938-2002)}

O intuito deste tópico é muito ambicioso, unindo uma narrativa que dê conta dos anos de governo direto de Ismet İnönü (1938-1950), da década de governo do Partido Democrático de Adnan Menderes (1950-1960) e dos muitos governos que se sucederam até o início do milênio, intercalados por três golpes militares, de fato, em 1960, 1971 e 1980, e por um golpe "pós-moderno", em 1997. Figuras como as de İnönü e Menderes, bem como as de Turgut Özal e Suleyman Demirel, destacam-se nesta fase, mas nenhuma delas ganha uma centralidade do porte da de Atatürk. Com todas as idas e vindas e a ascensão de grupos ligados a fortes ideologias de esquerda, direita e islamista, a república turca estabelecida por Atatürk se manteve, tendo militares com papel essencial. Os representantes do partido herdeiro de sua ideologia, o Cumhuriyet Halk Partisi (CHP), porém, cada vez mais passavam a ser vistos como corruptos, incompetentes e incapazes de resolver os problemas estruturais do país. Esse tópico divide-se em quatro subtópicos: os anos de Ismet İnönü (1938-1950), o governo de Adnan Menderes (1950-1960), as lutas internas de 1960 a 1980 e a contensão do conflito (1980-2002). 
Ismet İnönü (1884-1973) foi também um militar que integrou o CUP e lutou boa parte das últimas guerras do Império Otomano. Juntou-se ao Movimento Nacional na Anatólia, tornando-se o general que comandou as importantes vitórias nas chamadas batalhas de İnönü, de onde tirou seu sobrenome. Foi ainda o negociador responsável pelo armistício de Mudanya e do Tratado de Lausanne. İnönü foi várias vezes primeiroministro quando da presidência de Atatürk, e quando da morte deste, em 1938, tornou-se seu sucessor. Governou a Turquia, portanto, de 1938 a 1950. E diferentemente da fase anterior, as questões internacionais eram preponderantes em sua gestão.

Foi İnönü quem liderou a Turquia durante a Segunda Guerra Mundial, mantendo-a fora do conflito até sua fase final e equilibrada por boa parte do conflito, transitando entre os Aliados e o Eixo sem se comprometer, de fato, até 21 de fevereiro de 1945, quando, no final da guerra, se juntou aos Aliados - portanto, ao lado vencedor da guerra. Por um lado, havia assinado um pacto de não agressão com a Alemanha em 1941 e vendeu-lhe minérios até abril de 1944. Por outro lado, militares turcos, sobretudo pilotos, foram treinados na Grã-Bretanha; além disso, İnönü encontrou-se com Roosevelt e Churchill, na Segunda Conferência do Cairo, em dezembro de 1943, mas oficialmente não se comprometeu com eles. $\mathrm{O}$ convite para integrar as Nações Unidas, condicionado ao engajamento com o lado dos Aliados na guerra, teria sido uma das razões do envolvimento direto com o conflito. A Turquia participou então como membro fundador da Organização das Nações Unidas (ONU), oficialmente comprometendo-se com os ideais democráticos dos vencedores.

Apesar de permanecer neutra até o final, a guerra impactou enormemente a economia turca, com escassez de produtos e inflação, além de manutenção de muitos homens de sobreaviso nas Forças Armadas. Houve também muita hostilidade em relação às minorias, obrigadas a pagar, em 1942, parte do custo da guerra. A chamada taxa de propriedade (varlık vergisi) recaiu em grande medida sobre os judeus, gregos, armênios e levantinos, praticamente inviabilizando sua sobrevivência econômica no país (STONE, 2010, p. 159).

Se no pós-Primeira Guerra os soviéticos foram aliados importantes para a Turquia, no fim da Segunda Guerra Mundial mostravam-se ameaçadores, anunciando a não renovação do tratado de amizade, a não ser sob condições de estabelecimento de bases nos estreitos turcos, e demandando as províncias de Kars e Ardahan (ZÜRCHER, 2004, p. 208; STONE, 2010, p. 160), além de terem presença na Bulgária. O Pacto Molotov-Ribbentrop e a neutralidade da Turquia durante a guerra tinham já prejudicado suas relações. Temendo a política de Stálin na Europa Oriental, os EUA reavaliaram a importância estratégica da Turquia. Em 12 de março de 1947, o presidente Truman lançou a doutrina segundo a qual os EUA deveriam ajudar as "nações livres" cujas existências estivessem ameaçadas por pressão estrangeira ou por minorias militantes dentro de seu território. Nessa ocasião, ele pediu apoio militar e financeiro para a Grécia e a Turquia. Tratava-se do começo da defesa norte-americana de regimes anticomunistas pelo mundo (ZÜRCHER, 2004, p. 209).

No ano seguinte a Turquia passou a receber recursos do Plano Marshall e enviou 5 mil militares para a Guerra da Coreia (KARPAT, 2004, p. 10). Com İnönü ficava clara 
posição mais pró-Ocidente da República - na realidade, dessa vez mais alinhada aos EUA do que à Europa. Quando do fim da Segunda Guerra Mundial, o governo de Ismet İnönü tornou-se bastante impopular para a população por conta do controle total que teve sobre o país. De certa forma, o sentimento era de que o Estado fazia pouco, sobretudo para a massa de agricultores e operários, mas se mostrava extremamente presente na repressão (inclusive da religiosidade popular) e na coleta de impostos (ZÜRCHER, 2004, p. 206). Por conta da identificação do CHP com o aparato estatal sob um sistema de partido único, o ressentimento se deu em relação a ambos. İnönü, diante dessa pressão interna e das demandas de seus parceiros externos, permitiu então certa liberalização e a formação de uma oposição política.

A fase que vai de 1950 a 1960 foi o período de governo do Partido Democrático. Adnan Menderes governou a Turquia nesse primeiro experimento de democracia e economia liberal. Sendo um dono de terras rico da região de Aydın, próxima a Izmir, sua eleição como primeiro-ministro representou o fim dos 27 anos de governo de um só partido. Chegava ao poder apoiado por comerciantes, famílias semiaristocráticas, intelectuais, minorias, baixas classes médias urbanas e outros donos de terras (KARPAT, 2004, p. 15).

Os norte-americanos, que passaram a apoiar a Turquia no âmbito da chamada Doutrina Truman, com ajuda do Plano Marshall, tinham preferência por aliados democráticos. De fato, em parte graças a essa ajuda, novas estradas e escolas foram construídas, ampliou-se a rede elétrica e os investimentos feitos em infraestrutura, como transporte, comunicações e equipamentos para agricultura - melhorando a produção agrícola e industrial do país (POPE; POPE, 2004, p. 89).

Kemal Karpat (2004: p. 6) ressalta que essas transformações estão por trás de um tópico essencial para se entender a vida turca ainda hoje: o êxodo rural. Em 1950, 81\% dos turcos viviam em áreas rurais. Em 1997, 65\% já viviam em cidades. As mudanças elencadas fizeram com que muitos moradores de pequenas aldeias se sentissem atraídos pelo trabalho em fábricas, mudando-se para cidades como Istambul e Ancara. Esboçavamse então as primeiras gecekondu nas grandes cidades, isto é, as "construídas à noite", termo turco para favelas ${ }^{8}$.

A década de 1950 é fortemente marcada pelo aceite da Turquia como membro da Organização do Tratado do Atlântico Norte (Otan), em 1952. A integração a esta teve também um importante impacto militar na Turquia, em especial em como suas Forças Armadas eram desenhadas. Oficiais passaram a ser muito bem treinados, circulando pelos países do tratado e tendo acesso a equipamentos modernos.

Se por um lado a Turquia foi vista no âmbito da Doutrina Truman como próxima à Grécia, por outro, suas questões históricas com este país ainda se mantinham. Desacordos

\footnotetext{
${ }^{8}$ Essas migrações dos vilarejos para as cidades também tiveram profundo impacto no crescimento de centros urbanos e comerciais regionais, como Bursa, Kayseri, Denizli e Adana, que com o tempo desafiariam a autoridade do centro (KARPAT, 2004, p. 8).
} 
entre ambos a respeito do Chipre levaram à alegação de que um atentado à bomba fora feito ao consulado turco em Salônica (ex-território otomano, tornado grego em 1911), que funcionava na casa onde nasceu Atatürk. Deu-se então o chamado pogrom de 1955, em que populares tomaram as ruas de Istambul e danificaram os negócios não só de gregos como de não muçulmanos em geral.

Menderes governou em grande medida buscando enfraquecer o Partido Republicano, diminuindo sua influência entre burocratas, membros do sistema educacional e militar; tentando desmantelar a infraestrutura econômica estatista, trazendo em seu lugar a iniciativa privada; e se esforçando para aumentar o tamanho da classe média empreendedora (KARPAT, 2004, p. 17). Apesar de também ter agenda secular, mostrou-se menos belicoso em relação à religião. Permitiu a leitura do ezan (chamada para oração) em árabe e mostrou respeito pela cultura e identidade muçulmana dos cidadãos, proibindo, porém, a politização da fé.

A partir de 1954, no entanto, o governo mostrou-se cada vez mais autoritário e chegou ao fim de maneira traumática, seis anos depois. Acabou envolvendo-se com corrupção e enfrentando uma enorme inflação, que fazia com que oficiais das Forças Armadas se tornassem pobres, passando assim a ser odiado em círculos seculares. Seu governo foi derrubado pelo primeiro dos golpes militares no país, em 27 de maio de 1960.

Esse golpe se deu principalmente como uma reação das elites turcas contra o desafio populista das camadas mais baixas (KARPAT, 2004, p. 17). Nicole e Hugh Pope (2004, p. 91) ressaltam ainda que o descontentamento dos oficiais de baixa patente "empoderados" com o ingresso na Otan também teve papel importante nesse processo. A seu ver, esta não foi somente uma intervenção contra o governo do dia, mas também um golpe dentro das próprias Forças Armadas: uma rebelião de jovens oficiais contra seus "limitados superiores".

O primeiro-ministro, Adnan Menderes, foi preso em maio de 1960 com 415 parlamentares de seu partido. Foi julgado e considerado culpado por violar a constituição, sendo enforcado junto a seus ministros das finanças e do exterior (KARPAT, 2004, p. 18). Os apelos do Papa, do presidente Eisenhower e da rainha Elizabeth não foram levados em conta (STONE, 2010, p. 160).

O Comitê de União Nacional, junta militar que retirara Menderes do seu cargo, passou o poder para os civis. Os responsáveis pelo golpe militar achavam que poderiam enfrentar seus desafios se tivessem uma democracia que funcionasse propriamente. Deram-se novas eleições, sob o sistema de representação proporcional, e um Plano de Cinco Anos foi iniciado.

Na prática a sociedade turca mostrava-se claramente dividida. Ganhava força, cada vez mais, uma distinção entre esquerda - dominada por republicanos secularistas simpáticos às Forças Armadas e apoiados por grupos como os alevis - e direita - empresários da Anatólia com inclinações religiosas. Dois pequenos grupos também se avizinhavam: 
um islâmico, com origens em Konya, e outro nacionalista, com forte linguagem fascista (STONE, 2010, p. 161).

Foi também na década de 1960 que muitos turcos se mudaram para a Alemanha, França, Áustria e Holanda. A maioria deles foi para a Alemanha ajudar na reconstrução do país, onde criaram comunidades e espécies de guetos, ganharam cidadania e até mesmo posições no parlamento (KARPAT, 2004, p. 12). Os números são incertos, mas fala-se de certa de 3,5 milhões de turcos nesses países, e os recursos enviados por eles de volta para a Turquia têm peso muito importante na economia local. Por se configurarem como a maior diáspora na Alemanha, também têm um peso político importante nas relações bilaterais ${ }^{9}$.

Uma constituição foi promulgada em 1961, estabelecendo um legislativo bicameral. Figuras como Suleyman Demirel e Bulent Ecevit então ganhavam espaço, mas na prática foi um período muito agitado em termos políticos. Associações marxistas, maoístas e islamistas ganhavam força. Justamente sob o pretexto de se colocar contra ameaças islamistas antissecularistas, deu-se mais um golpe militar, dessa vez em 1971. Oficialmente, porém, o intuito era evitar que grupos marxistas chegassem ao poder (KARPAT, 2004, p. 21). Os militares não resolveram, contudo, as questões de inflação, dívidas e oferta precária de serviços, como eletricidade.

Foi justamente nessa época, em 1970, que o jovem norte-americano William Hayes, após passar uns dias de férias na Turquia, resolveu tentar levar para os EUA algumas gramas de haxixe junto ao corpo. Acabou preso no aeroporto Atatürk, em Istambul - num momento em que, por temor de ações guerrilheiras de sequestros de aviões no mundo todo, redobravam-se as práticas de segurança. Inicialmente julgado e condenado a alguns anos de prisão, teve sua pena comutada para prisão perpétua. Na prática, passou cinco anos preso, conseguindo fugir em 1975 para a Grécia e de lá retornando para os EUA, onde escreveu um livro de memórias. 0 filme $O$ expresso da meia-noite (gíria usada na prisão turca para quem conseguisse fugir), de 1978, baseou-se nessa obra e fez grande sucesso mundial, rendendo um Oscar ao roteirista Oliver Stone. 0 filme mostra tortura, sadismo, desonestidade e corrupção como elementos comuns a quase todos os turcos representados. Até muito recentemente, a obra ainda impactava a visão que muitos ocidentais tinham da Turquia e dos turcos ${ }^{10}$.

A grande questão de política externa nessa época foi a tomada do norte do Chipre, em 1974, tendo Bülent Ecevit no comando da Turquia. O país manteve ainda relativo desenvolvimento econômico, mas a vida política agitada envolvia cada vez mais violência. O CHP não conseguia trazer desenvolvimento econômico e social a fim de amainar as

\footnotetext{
${ }^{9} \mathrm{O}$ peso destas diásporas ficou muito claro em março de 2017 , quando se deram tensões políticas entre Turquia e Holanda e Turquia e Alemanha, em função do desejo do governo turco de fazer nesses países manifestações ligadas ao referendo que alteraria sua forma governamental, enfrentando resistência de ambos os países, em parte devido às suas próprias eleições internas.

${ }^{10}$ A premiada escritora turca, Elif Shafak, em sua palestra no TED Talk, ressalta o impacto desse filme ao reforçar estereótipos culturais sobre o turco, quando de sua infância, passada na Europa. Disponível em: <https://bit.ly/2Jlwrsq>. Acesso em: 8 jun. 2018.
} 
lutas. Os grupos de uma maneira geral demandavam que o Estado provesse serviços, mais do que slogans, e entre 1978 e 1980 a Turquia viveu uma guerra civil virtual. Por volta de 1979, "cerca de vinte pessoas eram mortas todo dia nas batalhas entre Esquerda, Direita e Islamistas, e as principais universidades tornaram-se campos de batalha" (STONE, 2010, p. 161, tradução minha).

O golpe militar de 1980 foi muito diferente dos dois anteriores. Seu intuito foi mais claramente salvar o Estado e a república e reformar o sistema político do que uma visão pontual, fazendo das Forças Armadas seus guardiões através do Conselho de Segurança Nacional. Dessa vez o poder direto foi mantido por mais tempo pelos militares, que governaram diretamente até 1983. 0 general Kenan Evren foi eleito presidente em 1982 e se estabeleceu uma nova constituição.

As Forças Armadas então se aproximavam de alguns elementos religiosos, entendendo o Islã como possível antídoto ao marxismo e aos separatistas curdos de esquerda. 0 ensino religioso passava a ser obrigatório nas escolas, e a religião voltava a tomar espaço - que o governo imaginava controlar. Nesse contexto, fez-se o convite para que Necmettin Erbakan, ex-líder do Partido Islâmico de Salvação Nacional, voltasse de seu exílio e estabelecesse um partido que também tivesse um apelo para a esquerda. Daí nasceu o Partido do BemEstar (Refah Partisi), uma mistura de nacionalismo turco com Islã.

Em 1983 o Partido Anavatan, de Turgut Özal, "ideologicamente ecumênico" (KARPAT, 2004, p. 23), ganhou as eleições e formou um governo que liberalizou a economia e o sistema político, desmantelando em grande medida a velha máquina estatal. Özal era originário de Malatya, na Anatólia oriental, e tinha passagem pelo Banco Mundial. Tratase de uma figura bastante importante por conta da sua complexidade, sendo ao mesmo tempo liberal e tradicionalista, meio curdo, claramente devoto ao Islã e ligado à ordem Nakşabandi ${ }^{11}$. Özal foi primeiro-ministro até 1987 e o homem da liberalização da economia e da visão estratégica da Turquia no Oriente Médio, buscando apoio de instituições como a Organização Internacional do Comércio e o Fundo Monetário Internacional (FMI). Deu-se o que alguns chamam de boom econômico (KARPAT, 2004, p. 24; STONE, 2010, p. 162). Özal tornou-se presidente em 1989 e manteve esse cargo até 1993, quando faleceu de ataque cardíaco.

Muitos autores ressaltam o papel de Özal a ponto de compará-lo ao papel de Atatürk como um dos arquitetos da Turquia moderna. Karpat (2004, p. 24) ressalta, porém, que ele foi também responsável por um alto grau de corrupção e de negligência do que seriam as tradições positivas de bom governo.

\footnotetext{
${ }^{11}$ Ordem sufi estabelecia em Horasan, Pérsia, no século XIV, pelo Sheikh Muhammad Bahattin al-Bukhari. Chegou à Anatólia no século seguinte com o Sheikh Ilahi Nakşibendi. Logo se espalhou pelo Império Otomano, tornando-se muito influente. Essa tarikat periodicamente se envolvia com atividades políticas tidas como subversivas e por vezes se opunha a reformas do Estado de maneira violenta. Existiam quinze subgrupos no Império Otomano, e ainda hoje alguns subsistem. Atualmente os membros se envolvem em atividades dentro de congregações religiosas (cemaat) (RUBIN; HEPER, 2002, p. 71).
} 
Nos anos 1990 a pluralidade de partidos e suas lutas internas chamavam muita atenção no país. Foi um importante período de ensaio da atuação de partidos islâmicos, que tiveram a prefeitura de importantes cidades, como Istambul, em seu portfólio. A passagem de Necmettin Erbakan pelo cargo de primeiro-ministro de 1996 a 1997 foi, entretanto, problemática. Suas muitas viagens a países muçulmanos foram entendidas como a tentativa de criar um eixo islâmico, eventualmente afastando a Turquia da aliança com o Ocidente. Erbakan acabou pressionado a se afastar pelos militares, sendo banido da política por violar a separação entre estado e religião.

O período de 1984 a 1999 foi a fase dura da insurgência do Partido dos Trabalhadores do Curdistão (Partiya Karkerên Kurdistanê, PKK), gerando cerca de trinta mil mortos na Turquia e uma ampla repressão por parte do governo contra seus membros. A comunidade internacional comumente se pronunciava a respeito dos direitos humanos dos curdos, e este era um dos temas espinhosos das relações internacionais da Turquia. A prisão do líder do PKK, Abdullah Ocalan, em 1999, e a comutação de sua pena de morte por prisão perpétua são entendidos como um passo da Turquia na direção de demandas da União Europeia. De fato, em dezembro daquele ano em Helsinque, capital da Finlândia, os 15 líderes da União Europeia declararam que "a Turquia é um Estado candidato a se juntar à União nas bases dos mesmos critérios aplicados a outros estados candidatos" (DISMORR, 2008, p. 47, tradução minha). Depois de 40 anos como o demandante mais longevo da entrada na comunidade europeia, pôde sair da sala de espera e ter sua candidatura oficializada.

\section{Os governos AKP e os dilemas da Turquia atual (2003-2018)}

Em obra que pretende apresentar a Turquia para o mundo ocidental a partir de sua experiência no país, a embaixadora sueca Ann Dismorr (2008, p. 13) lançava logo na introdução uma questão que se colocava para muitos quando do início do governo do AKP: “será o primeiro-ministro Erdoğan o último islamista ou o primeiro democrata?". A pergunta ainda está em aberto, e o intuito neste tópico é tratar da gestão do AKP, justamente tentando entender sua complexidade, subdividindo-a em dois recortes: 1) 2003-2013: os "bons" anos como primeiro-ministro; 2) 2013-2017: de um período de revoltas à tentativa de golpe e os desafios correntes.

Recep Tayyip Erdoğan nasceu em 1954 no bairro de Kasımpaşa, no lado europeu de Istambul. Sua família é oriunda de Rize, na região do Mar Negro. De origem humilde, estudou em escola religiosa e chegou a vender limonada e simit - pão circular coberto com semestres, popular na Turquia - nas ruas da cidade para complementar a renda. Formou-se em Administração na bem reputada Marmara University, em 1981, mas desde o ensino médio já atuava em entidades políticas. Nessa mesma época chegou a jogar profissionalmente futebol. 
De 1994 a 1998 foi prefeito de Istambul pelo Partido do Bem-Estar. Sua gestão foi muito bem-sucedida, enfrentando problemas crônicos da cidade, como falta de água e de tráfego urbano, e essa atuação lhe deu projeção nacional, embora tenha tido final controverso. Por conta da declamação de versos interpretados como islamistas, em 1997 foi condenado a dez meses de prisão, tendo cumprido quatro destes de fato atrás das grades.

Na realidade, ocorreram então os chamados "processos de 28 de fevereiro". Nesse dia, o Conselho de Segurança Nacional, liderado por militares, formulou decisões que declararam o "fundamentalismo islâmico" na Turquia tão perigoso quanto o separatismo curdo (ATACAN, 2006). Este era visto como ameaça à estabilidade do país, e demandouse do Ministério da Educação reformas a fim de enfraquecer escolas privadas financiadas por associações religiosas e o fechamento de escolas públicas religiosas, bem como de seminários corânicos (YAVUZ, 2003). Quando o governo Erbakan hesitou em implementar tais diretrizes, foi forçado pelos militares no que ficou conhecido como "golpe pósmoderno", ou "soft coup".

Em 2001, Erdoğan foi um dos fundadores do AKP - também chamado de AK Partisi ou Partido Branco, em alusão a sua "pureza", ou seja, não envolvimento com a corrupção -, que chegou ao poder no ano seguinte e desde então lá se mantém.

Quando o partido foi eleito nas eleições gerais de 3 de novembro de 2002, Erdoğan não pôde assumir de imediato o cargo de primeiro-ministro por estar ainda em fase de banimento por suas declamações de poemas, tidos como islamistas. Abdullah Gül ocupou o cargo por quatro meses até Erdoğan poder assumir de fato o poder.

Essas eleições, porém, são consideradas responsáveis por uma transformação importante no curso da história da república turca. Levadas a cabo em um dos momentos mais difíceis da economia do país, o partido AKP se apresentava com agenda islâmica moderada, prometendo negociações sobre a entrada na União Europeia e a criação de estabilidade política, a fim de com isso melhorar a economia. Largo desemprego, corrupção e descontentamento generalizado com políticos geraram interesse pela novidade e pelo frescor propostos pelo AKP.

Há quem inclusive diga, como ressalta Ann Dismorr (2008, p. 69-72), que a agenda pró-União Europeia foi importante também em termos externos, pois gerou uma rede de apoio de líderes internacionais, criando com isso certo grau de proteção contra as ameaças legais ao partido e a seu líder. Havia a ameaça real de que o AKP fosse banido, mesmo depois de democraticamente eleito. A ideia de que o Estado era o pilar e o protetor do secularismo turco ainda grassava. Apesar de toda a controvérsia que a envolveu, a eleição acabou com décadas de governos de coalizão fraca, bem como com o longo período de política fragmentada (DISMORR, 2008, p. 73).

Os turcos, segundo comprovaram pesquisas da época, estavam mais preocupados com desemprego, economia e inflação do que com religião. De fato, com a chegada do AKP ao poder, a economia foi estabilizada, e a inflação reduzida, além de terem sido feitos muitos esforços para a integração à União Europeia. 
Ampliaram-se as exportações, encarou-se finalmente a "questão curda" e esvaziouse o papel dos militares. Uniu-se no discurso um forte apelo ao passado otomano (SOCHACZEWSKI, 2013) a ganhos obtidos com a república. Os índices de aprovação eram enormes nos dois mandatos de Erdoğan como primeiro-ministro, o que se estremeceu no ano de 2013.

A política externa tem papel importantíssimo, sobretudo, na fase inicial do governo do AKP. Tendo o professor de relações internacionais Ahmet Davutoğlu primeiro como seu assessor de assuntos de internacionais (2002-2009) e depois como ministro das relações exteriores (2009-2014), Erdoğan levou adiante uma política externa bastante ativista, não só com maior seriedade em relação à demanda por ingresso na União Europeia como também buscando diversificar as relações com o mundo todo. Foi nesse contexto, por exemplo, que se deu a visita do presidente Luís Inácio Lula da Silva à Turquia, em 2009; o estabelecimento de voo direto entre esse país e o Brasil; o crescimento do turismo em ambos os lados e parcerias importantes na arena internacional, como a já citada Aliança das Civilizações; além da tentativa conjunta de mediação em relação ao Irã, conhecida como Declaração de Teerã (LEVAGGI; FEREZ, 2016).

A professora de relações internacionais da Bilkent University, Pınar Bilgin (2015), entende o ativismo do AKP em relação ao Oriente Médio como uma nova visão da região, a ser somada às tradicionais visões de Oriente Médio, Oriente Médio Árabe, Oriente Médio Mediterrâneo e Oriente Médio Muçulmano, e contraposta ao que chama de "Al Midan", uma perspectiva popular e humanista, de baixo para cima (BILGIN, 2015). Ela denomina de "espaço geopolítico otomano" a visão de Davutoğlu, que inclui ativismo diplomático nos antigos territórios otomanos e também em áreas em que vivem muçulmanos e povos turcos. A seu ver, mais do que uma perspectiva de segurança regional, trata-se de uma visão dos interesses turcos. "Procura-se a revisão da segurança regional, tendo em vista a insegurança da Turquia, formulada em termos de expansionismo econômico com uma adição de culturalismo" (BILGIN, 2015, tradução minha).

A gestão de Erdoğan como primeiro-ministro se apresentou como "conservadora democrática", embora tendo claras tendências islâmicas, não atentando de início às liberdades religiosas no país. Empenhou-se claramente em uma maior diversificação das parcerias internacionais, retomando, inclusive, o contato com países do Oriente Médio e estabelecendo de fato relações que antes eram só protocolares, com países como o Brasil. 0 foco se deu principalmente na economia, com grande sucesso em atrair investimentos estrangeiros. A visão do primeiro governo do AKP foi, em grande medida, bem-sucedida.

0 chamado caso Ergenekon, de 2007, é um ponto importante de se ter em mente, no entanto, por ser considerado por alguns como um acontecimento que consolidava o controle dos civis sobre os militares, enfraquecendo seus apoiadores e indicando uma maturidade da democracia turca, e por outros como um indício claro de tendências autocráticas do governo, uma vez que os processos se deram de maneira questionável. 
Tudo teria começado com uma ligação de rotina para a polícia com indicações de armamentos escondidos em um subúrbio de Istambul. A polícia teria então desmantelado uma rede de secularistas ultranacionalistas, integrada por membros de oposição do parlamento, acadêmicos, políticos, jornalistas, além de militares, com o projeto de derrubar o governo. Mais de duzentas pessoas foram presas e muitas foram condenadas por conspiração para derrubar o governo (BILEFSKY, 2009).

Em junho de 2013 ocorreu, porém, um evento que deixava claro o crescimento de fissuras na sociedade turca, que estava bastante polarizada. Inicialmente ambientalistas e alguns ativistas ligados a questões urbanas se mobilizavam contra a construção de um shopping center em um dos últimos pontos verdes em Istambul, o Parque Gezi, ao lado da famosa Praça Taksim. As manifestações pacíficas foram, porém, reprimidas de maneira extremamente violenta por parte do governo, e imagens dessa violência rapidamente correram pelas redes sociais. Aquela região e depois cidades de quase todo o país acabaram tomadas por manifestantes que passavam claramente a reclamar da agenda crescentemente autoritária do governo - ao dificultar enormemente a venda de bebidas alcoólicas, impor obras faraônicas sem consulta popular, entre outros - e também por demandas diversas de grupos minoritários, como os curdos ou de questões de gênero.

Outra mudança importante na rede que sustentava o AKP foi o rompimento deste com o movimento Hizmet, liderado pelo imam Fetullah Gülen, residente na Pensilvânia desde 199912. Por serem aliados importantes na primeira fase, com integrantes do grupo tendo papel relevante no chamado caso Ergenekon, o rompimento de 2013 acabou se tornando uma luta intraislamista, com o AKP desde então enfraquecendo o grupo econômica e politicamente - fechando suas escolas, intercedendo em seus negócios e tentando atingilo em suas ações em outros países -, com sérias alegações de que o grupo esteja por trás da tentativa de golpe militar, que envolveu tentativa de matar Erdoğan, em julho de 2016 (SOCHACZEWSKI, 2016). 0 país vive desde então em "estado de emergência", já renovado seis vezes por seu parlamento (STATE..., 2018).

Se a trajetória até 2013 era em grande medida ascendente, desde então é controversa. Erdoğan candidatou-se e foi eleito presidente da República em 2014, pela primeira vez de maneira direta, já tendo se distanciado do Hizmet. Seus planos de uma mudança tranquila da constituição, de modo a dar mais poder à presidência no país parlamentarista, porém, se viram impactados com ascensão do Partido Democrático do Povo (Halkların Demokratik Partisi, HDP), em 2015. Esse partido nascido em 2012, mas fortalecido com as revoltas de Gezi, com agenda que englobava a questão curda, de gênero, de minorias e mesmo ambiental, chegou ao parlamento com grande barulho. Desde então, Erdoğan mudou sua retórica

\footnotetext{
12 O movimento apresenta-se como "inspirado" no imam em questão, "enraizado na tradição espiritual e humanista do Islã", atuante nos setores social, cultural e educacional, em quase todo o mundo. Conta com um braço brasileiro desde 2011, o Centro Cultural Brasil-Turquia, com forte atuação em São Paulo, Brasília e Rio de Janeiro. Apresentam-se como não políticos e com plataforma de diálogo entre civilizações (CENTRO CULTURAL BRASIL-TURQUIA, 2016). Uma pesquisa rápida sobre suas atuações no Brasil, porém, pode facilmente apontar sua forte atuação política mesmo no Brasil, organizando eventos na Câmara dos Vereadores de São Paulo (CENTRO CULTURAL BRASIL-TURQUIA, 2017) e financiando viagens à Turquia de políticos como o senador Cristóvão Buarque (CENTRO CULTURAL BRASIL-TURQUIA, 2014).
} 
para uma linha mais nacionalista, cada vez mais reticente em relação à União Europeia e aos Estados Unidos, mudando sua base de apoio, majoritariamente de liberais, curdos e "gulenistas", num primeiro momento, para nacionalistas e eurasianistas, na fase atual.

\section{Considerações finais}

Em 2023 República da Turquia celebrará seu centenário. Desconfia-se que o líder que então estará à frente do país será o mesmo que atualmente senta na presidência: Recep Tayyip Erdoğan. Em função do resultado do referendo de 16 de abril de 2017, ele poderá acumular no mesmo cargo a chefia de Estado e de governo, podendo ficar no poder até 2029 (BELLAIGUE, 2017).

Se por um lado Erdoğan inicialmente forjou alianças com curdos e o movimento Hizmet, apresentando-se como "democrata conservador" e atuando em grande medida com roupagem democrática, desde 2013 isso mudou de figura. Partidos democraticamente eleitos, como o citado HDP, além de críticos não violentos de sua política, como muitos jornalistas e acadêmicos, vêm sendo tratados da mesma maneira, se não de modo pior, que integrantes de grupos que usam táticas terroristas - como PKK, Falcões da Libertação do Curdistão (TAK) e Estado Islâmico - ou que procuraram derrubá-lo, como no golpe frustrado de 15 de julho de 2016. Este parece ser o caso do Hizmet: o governo turco vem usando desde então as iniciais FETÖ, algo como "Organização Terrorista do Fethullah", para impingir um caráter terrorista a esse grupo, que no passado havia sido seu aliado.

Erdoğan atua, em certo sentido, de forma similar à Atatürk, em 1926, quando aproveitou a tentativa de matarem-no para se livrar de todos os inimigos ou eventuais amigos que ameaçassem sua posição. Vale ainda ressaltar que seus importantes aliados de primeira hora, como o presidente Abdullah Gül e o primeiro-ministro Ahmet Davutoğlu, provavelmente os líderes com maior potencial de ameaça, foram afastados nos últimos tempos.

De forma muito sintética, vislumbramos aqui a história de uma república dividida em três fases importantes. A primeira delas foi a da criação de uma nova entidade política, das poucas que se mantiveram íntegras e independentes das ações europeias no Oriente Médio no pós-Primeira Guerra Mundial, bastante focada na figura de Mustafá Kemal Atatürk. A autonomia em relação aos europeus se deu a custo de bastante sangue e negociação política, é preciso frisar, e da percepção de ser mais importante voltar-se para dentro e forjar uma nação com história antiga e sofisticada, remetendo a civilizações anatolianas, como hititas e frígios, e silenciando sobre o passado otomano, além de ter sua língua recodificada, usando agora signos latinos. Lutava-se contra os europeus nos campos de batalha e nas arenas políticas, mas estes claramente serviam de inspiração em termos políticos, sociais e mesmo econômicos.

A segunda fase aqui tratada é a de um longo período de governos fracos e de política fragmentada em que se destacaram, sobretudo, os militares e suas intervenções. 
Se Atatürk teve lida pontual com questões internacionais, liberado assim para tratar de seu projeto interno, o mesmo não se deu com Ismet İnönü, que liderou o país durante a Segunda Guerra Mundial, tirando o melhor possível da chamada "neutralidade ativa". Se por um lado conseguiu evitar o fiasco da Primeira Guerra Mundial por conta do envolvimento precipitado com a Alemanha, por outro, os dispêndios da prontidão para o possível envolvimento no conflito - que de fato se deu em seus estertores - tiveram alto custo político.

O claro apoio norte-americano no imediato pós-guerra, já no contexto da Guerra Fria, trouxe auxílio financeiro ao país para obras importantes, mas exigiu democracia de fato. Foi assim que se chegou a década de Adnan Menderes, inicialmente eivada de esperança de um governo democrático, mostrando-se, no fim, bastante inapto para lidar com os problemas do país. Foi então a desculpa para a primeira intervenção militar, de 1960 . As duas décadas seguintes seriam de crescentes conflitos políticos, quando militantes de esquerda e de direita se enfrentavam diretamente e o governo entendeu, em determinado momento, que o Islã, banido por tanto tempo, poderia ser uma contraposição importante para estes. Dessa forma, nos anos 1980, diminui o preconceito oficial com o governo de Turgut Özal e experiências partidárias como o Partido do Bem-Estar se esboçam. Estes seriam importantes ensaios para a criação do AKP, que governa o país atualmente. Foi nesse "intervalo", também, que se deu a ação mais sangrenta de grupos curdos, como o PKK. De 1984 a 1999, cerca de 30 mil turcos foram mortos em função da luta desse grupo contra o estado e seus desdobramentos.

Por fim, na fase atual, a República da Turquia, apesar de ainda se manter como membro da Otan e pleitear o ingresso na União Europeia, cada vez mais se vê identificada com governos autoritários, como o da Rússia, esboçando crescentemente uma agenda "eurasianista"13.

Em 2018 Erdoğan se iguala de fato aos 15 anos de poder de Atatürk, e a questão que muitos se colocam é: em que medida, mais do que querer ultrapassar em glória e feitos o "pai dos turcos", ele ambiciona que seu projeto se assemelhe ao tipo de poder dos predecessores sultões otomanos? Em que medida, mais do que representar uma reconciliação do modernismo turco e do Islã baseada numa interação entre fé e racionalidade (KARPAT, 2004, p. 1), a eleição do AKP acaba se mostrando um retrocesso na direção de uma liderança "crente, paranoica e crescentemente absolutista" como no do sultanato de Abdul Hamid II, conforme apregoa Christopher de Bellaigue (2017, tradução minha)?

\footnotetext{
${ }^{13}$ Posição defendida por empresários com sólidos investimentos na Rússia, por um lado (sendo, portanto, pragmáticos), mas também por Dogu Perincek, do Partido Nacional (Vatan Partisi), mais ideológico, que parece acreditar em conspiração ocidental antiturca e articula lobby pró-russo.
} 
artigo

\section{Referências bibliográficas}

ATACAN, Fulya. Exploring Religious politics at the Crossroad: AKP-SP. In: ÇAKOĞLU, Ali; RUBIN, Barry. Religion and politics in Turkey. London: Routledge, 2006. p. 45-58.

BELLAIGUE, Christopher de. Turkey: the return of the Sultan. The New York Review of Books, New York, 9 Mar. 2017. Disponível em: <https://bit.ly/2lHRt8R>. Acesso em: 11 mar. 2017.

BERKES, Niyazi. The development of secularism in Turkey. London: Hurst \& Company, 1998. BILEFSKY, Dan. In Turkey, trial casts wide net of mistrust. The New York Times, New York, 21 Nov. 2009. Disponível em: <https://nyti.ms/2Jpcpgs>. Acesso em: 14 mar. 2017.

BILGIN, Pinar. Regional security in the Middle East: what is what we seek. Center for Mellemoststudier, Odense, Sept. 2015. Disponível em: <https://bit.ly/2xQHynC>. Acesso em: 6 jun. 2018.

BILGIN, Pınar. Whose Middle East? Geopolitical Inventions and Practices of Security. International Relations, Thousand Oaks, v. 18, n. 1, p. 17-33, 2004.

CENTRO CULTURAL BRASIL-TURQUIA. São Paulo, 2016. Disponível em: <https://bit. ly/2kZnF4I>. Acesso em: 17 mar. 2018.

- CCBT e Câmara Municipal De São Paulo organizam Comemoração do Dia da Comunidade Turca. São Paulo, 7 jul. 2017. Disponível em:<https://bit.ly/2LCpqQG>. Acesso em: 17 mar. 2018.

. Senador Cristovam Buarque viaja à Turquia a convite do CCBT. São Paulo, jul. 2014. Disponível em:< https://bit.ly/2HwkA4Y>. Acesso em: 17 mar. 2018.

DISMORR, Ann. Turkey decoded. Lebanon: SAQI, 2008.

FINDLEY, Carter Vaughn. Turkey, Islam, Nationalism, and Modernity. A History, 1789-2007. New Haven: Yale University Press, 2010.

KARPAT, Kemal. Studies on Turkish Politics and Society. Leiden: Brill, 2004.

KINROSS, P. B. Atatürk: a biography of Mustafa Kemal Atatürk, father of modern Turkey. New York: William Morrow and Company, 1965.

LEVAGGI, Ariel González; FEREZ, Manuel (orgs.). Turquía-América Latina y el Caribe. Una asociación emergente. Istanbul: Bahçeşehir Üniversitesi Yayınları, 2016.

LEWIS, Bernard. The emergence of Modern Turkey. New York: Oxford University Press, 1968.

LOUREIRO, Heitor de Andrade Carvalho. Pragmatismo e humanitarismo: a política externa brasileira e a causa armênia (1912-1922). 2016. 230 f. Tese (Doutorado em História) Faculdade de Ciências Humanas e Sociais, Universidade Estadual Paulista, Franca, 2016.

MANGO, Andrew. The Turks Today. London: John Murray, 2004. 
artigo

POPE, Nicole; POPE, Hugh. Turkey unveiled. A History of Modern Turkey. New York: The Overlook Press, 2004.

RUBIN, Barry; HEPER, Metin (eds.). Political parties in Turkey. London: Frank Cass, 2002.

SOCHACZEWSKI, Monique. Do Rio de Janeiro a Istambul: contrastes e conexões entre o Brasil e o Império Otomano (1850-1919). Brasília, DF: Funag, 2017.

SOCHACZEWSKI, Monique. A batalha das narrativas em torno da crise turca. Mundorama - revista de divulgação científica em Relações Internacionais, Brasília, DF, 4 set. 2016. Disponível em <https://bit.ly/2JffwaJ>. Acesso em: 6 jun. 2018.

__. "Otomania" na Turquia Contemporânea. Belo Horizonte: Abri, 2013.

STATE of emergency in Turkey extended for sixth time. Hürriyet Daily News, Istanbul, 18 Jan. 2018. Disponível em: <https://bit.ly/2Jsj2ul>. Acesso em: 19 mar. 2018.

STONE, Norman. Turkey. A short history. London: Thames \& Hudson, 2010.

YAVUZ, Hakan. Islamic political identity in Turkey. Oxford: Oxford University Press, 2003.

ZÜRCHER, Eric J. Turkey: a modern history. New York: I. B. Tauris, 2004.

Texto recebido em: 30 de Janeiro de 2018 Aprovado para publicação em: 18 de Março de 2018 